Olivera Ilić

Archaeological Institute, Belgrade

o.ilic@ai.sanu.ac.rs

Snežana Golubović

Archaeological Institute, Belgrade

arheosneska@gmail.com

Nemanja Mrđić

Archaeological Institute, Belgrade

nemanjamrdjic@gmail.com
UDK 904:355.692.1"652"(398)

Original research article

Received: June 03, 2010

Accepted: August 02, 2010

\title{
SUPPLYING AND TRANSPORT ALONG DANUBE LIMES IN THE UPPER MOESIA
}

\begin{abstract}
This paper deals with supplying Roman troops along the Limes and in the hinterland of the province Upper Moesia. The system of supplying and distributing of goods was conducted both on river and land communications throughout the entire Roman period.

According to the archaeological evidence, apart from larger supply units, in which food supplies were kept for further distribution (Poreckka reka, Horreum Margi), forts along the Limes also had buildings intended for keeping food supplies, which again could satisfy needs of soldiers for a certain period of time.
\end{abstract}

\section{Key words: supplying, supply centre, the Danube Limes, river port, Upper Moesia.}

Since historical evidence about supply of Roman troops along the Limes, but also in the hintreland of the province, are poor, archaeological data gain on importance. By relying on them, we shall attempt to reconstruct ways of supplying and transporting goods in this region, which was of the highest importance during Roman times.

During the last decades, within Roman provincial archaeology, great attention has been paid to supplying army - both units stationed within permanent camps, as well as troops during military campaigns. Here, this question was not studied enough and therefore the results gained are very modest so far. In this sense, this paper could represent an introduction to further study of supply and transport of goods and other products. Durign the past few decades in Serbia, the question of supplying Roman troops was most studied by Petar Petrović (Петровић 1980; Петровић, 1983; Петровић, 1991).

Troop supply represents a complex problem (Roth 1999; Breeze 2000; Thomas and Stallibrass 2008; Kehne 2007; Herz 2007). In this paper, no problems shall be analyzed related to supply during marches, outside camps and on hostile territories. We will deal with supply of

* The article results from the project: Viminacium, Roman city and military legion camp - research of material and non material of inhabitants by using the modern technologies of remote detection, geophysics, GIS, digitalisation and $3 D$ visualisation (no 47018), funded by Ministry of Education and Science of the Republic of Serbia. 
garrisons and units stationed in their permanent camps. Actually, unit supplying during marches and on hostile territories represents a study of a different kind and could be an object of study of some paper in the future.

When the Limes of Upper Moesia is concearned, two aspects can be analyzed:

- the first concearns geographical regions and is directly related to relief of the terrain:

a) the area from Singidunum to the Iron Gates, b) the Iron Gates themselves and c) the area downsream from the Iron Gates.

- the second concearns troop supplying according to their ranking - legions or auxiliary troops;

When geographical aspect is concearned, one can clearly distinguish three regions along the Danube Limes, each of them possessing its own specific features (Map 1.).

The first region includes the territory from Singidunum (Belgrade) to the Cuppae (Golubac), at the entrance of the Iron Gates. This area is plain, convenient for agriculture and concentration of large military formations. At this territory, both legions forming the main defence of the Up- per Moesia were stationed. In other words, the nucleus of defence was concentraded exactly where it was easy to supply large numbers of troops and even more, part of supply was conducted by legions themselves. Of main importance was that the area was of agricultural character. Around each and every legionary camp there was a so called territorium, land given to legions so that they could fulfill their basic needs, first of all food production, but also building material (bricks). Prata legionis was also mentioned in sources and inscriptions, used by a legion for its purposes, but it remains unclear whether prata legionis represents the same thing as territorium legionis (Mocsy 1967: 41; Mocsy 1972: 133-168; Zaninović 1985: 63-79; Mason 1988: 163-189).

From a series of possible explanations given by Bohec, one can sort one out, also expressed by Schulten (Bohec 2000: 219), that the prata legionis included pastures, forests and fertile fields, clay deposits etc., while territorium includes the complete area under legion's supervision and which practically formed an military administrative unit. In this sense, a territorium would include canabae and workshops which were built outside

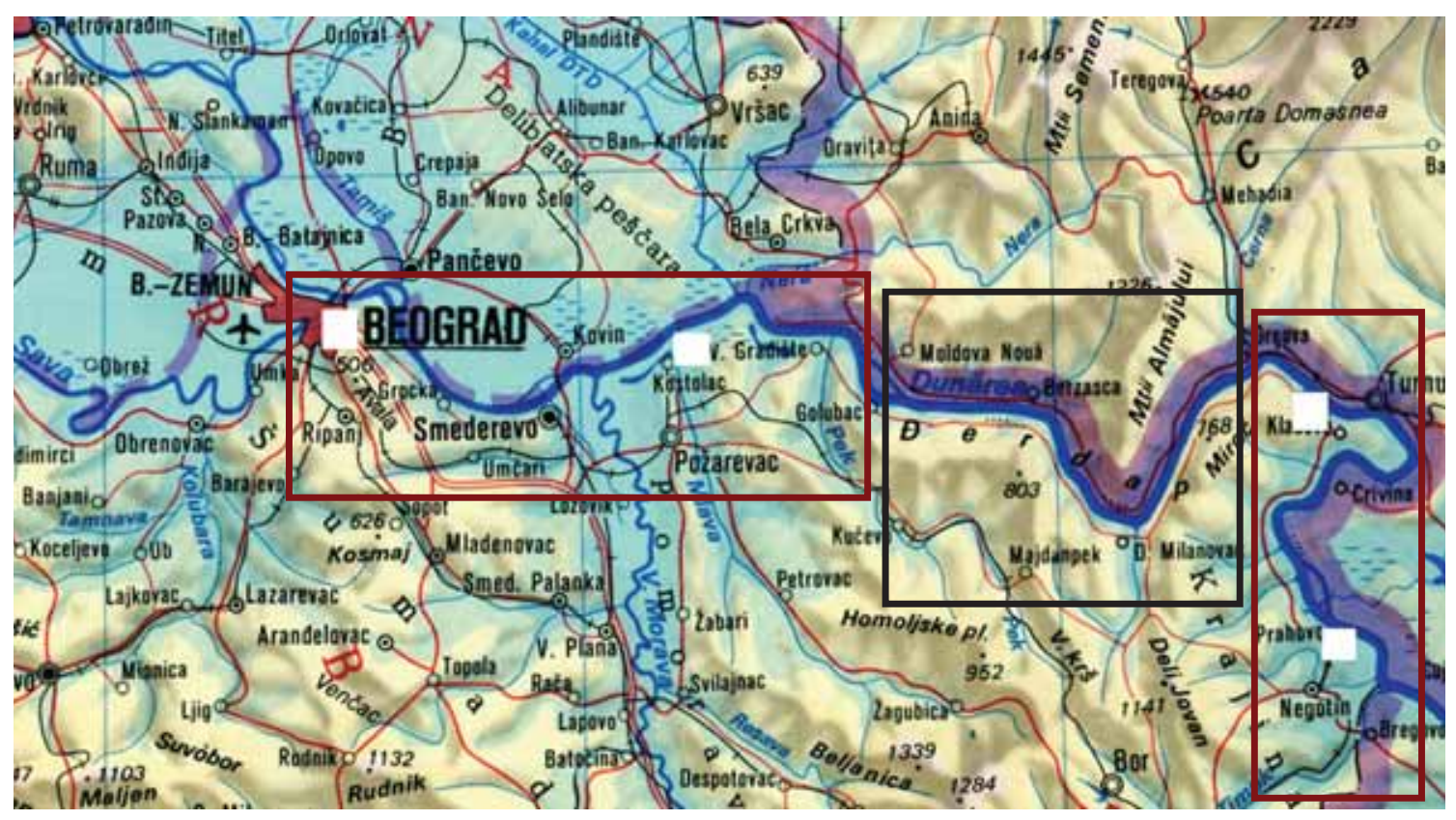

Map 1. Danube Limes in Upper Moesia (Moesia Superior) 
the camps. Finaly, altough canabae were settlement of civilians and territorium could spread around civilian settlements these were strictly under military government.

The problem of military territories is most of all present in bordering areas, actually Limes along the Rhine and the Danube, where numerous camps were built with large number of soldiers who needed to be supplied with food, weapons, equipment and other goods.

In this sense, the question of the area covered by a prata legionis or a territorium legionis arises. In the first place, the size of legion's territory depended on the number of soldiers for which supplies were needed, but for which exercising area was needed as well. According to a milestone, one found out that the Prata legionis of the legion III Macedonicae in Asturia measured about $560 \mathrm{~km}^{2}$ (Mason 1988: 164). Prata legionis did not supply soldiers only with grain. Each legion had a squad of about 120 cavalrymen plus additional mules and oxen used for transport of legionary supplies. Food for animals was not less of a problem. It was partly solved due to the fact that military also controlled numrous pastures which usually included several hundreds of hectars. According to some authors, livestock could have included up to several thousands of animals (riding horses, workhorses, pulling animals: mules, oxen, for food: sheep and goats) (Zaninović, 1985: 67).

Livestock was concearn of special services in particular legions pecuarii and veterinarii (CIL III 11215 i CIL XIII 8287; Tacit, Annales XIII, 55: pecora et armenta militum). Agriculture and stock-breeding as a part of activities of non-military character surely reduced supplying and costs. Grain, as main food, was mostly grown on legionary fields. Soldiers could have also bought food from numerous land-owners of the fields around Singidunum, Margum or Viminacium.

Vicinity of rivers was a great advantage for all of the camps built along the Limes, since it made fishing possible. Still, annona militaris and the principle of legionary supplying from civilian sources in the form of taxes collected in goods was of main importance, because it was not possible to produce enough food from the prata legionis alone.

The second geographic region includes the Iron Gates (Map 2.). In this area, military units were stationed up to the rank of a cohort. The

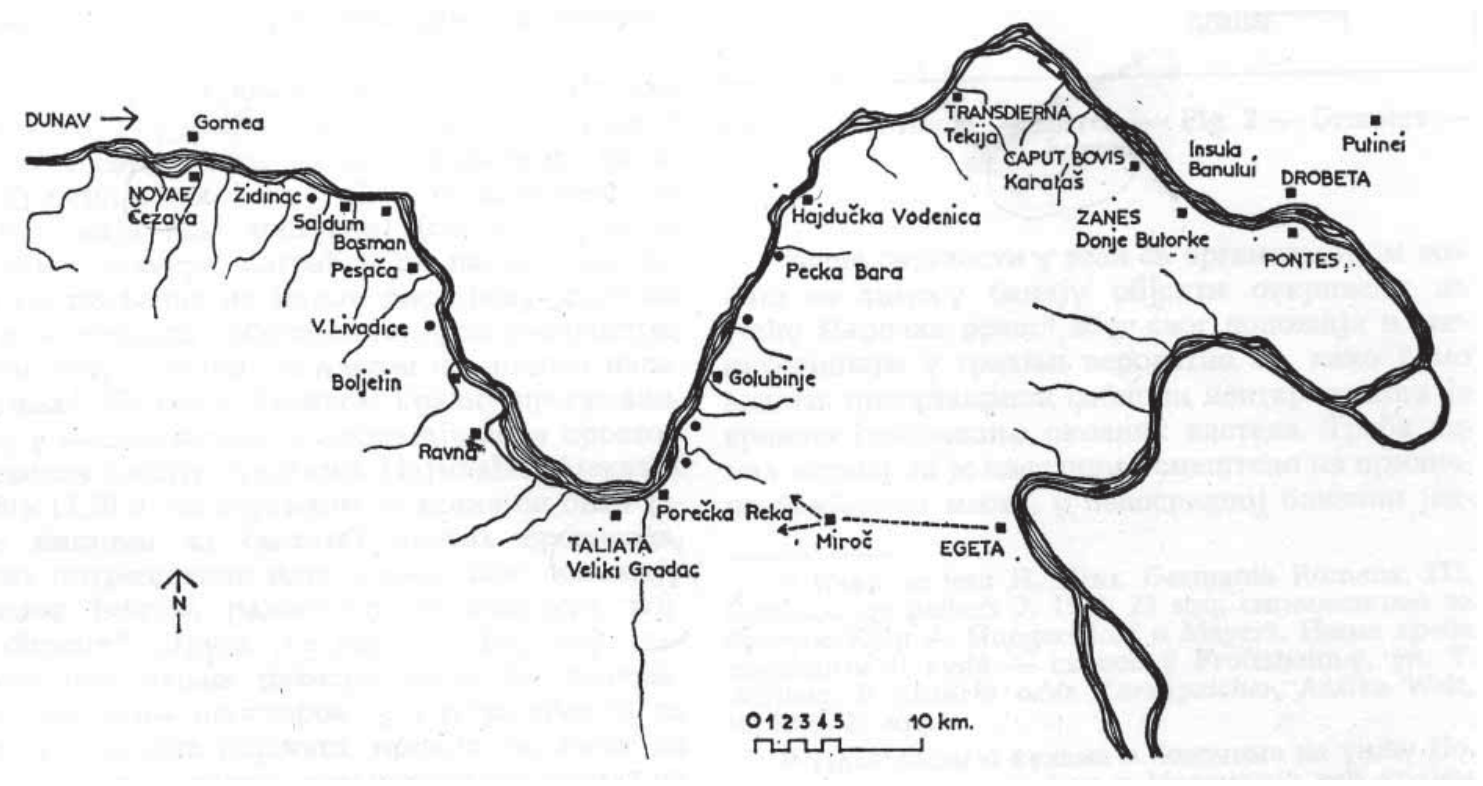

Map 2. Fortifications along Danube limes in the Iron Gate (П. Петровић 1981, fig. 1) 
gorge itself did not represent an area adequate for agriculture, so, apart from Porečka reka, the needs of these units had to be satisfied by transporting food from supply centers situated mostly in the hinterland (Horreum Margi). Smaller number of soldiers within such a unit was an advantage, but the size of fortifications (quadriburgium, speculum) represented a problem, since they, apart from several exceptions, were very small and did not possess a granary or any other similar building suitable for keeping food supplies for a longer period of time. This led to regular, short term, food supplying in which supply centers were permanently engaged, while each fortification was supplied periodically. One could of course presume that the vicinity of rivers made fishing possible, but one can only conclude this freely, since there are no data about it in written sources.

The third geographic region included the area downstream from the Iron Gates, in which again larger fortifications were built (Statio Cataractarum Dianae, Pontes, Egeta). This area was not suitable for long-term stationing of legions, since around these military camps there were not enough fields for crop growing. Units up to the size of a cohors militaria could have possessed a equivalent of territorium around their camps.

Speaking about other aspects of supplying, it is certain that they depended on rank and size of a military unit. Due to a large number of soldiers, legionary units were supplied with much more food and other goods needed for active service. Legionaries comparing to auxiliary soldiers were also entitled to a larger amounts of provisions.

The system of supplying the military with food arises many questions concearning mostly the problem whether food was brought from distant areas or areas in vicinity, ie. from the local population. There is no doubt that olives, oliveoil, garum, better quality vine and tropical fruits were brought from distant areas, because amphora-finds throughout the Empire give testimony about it (Bjelajac, 1996: 109).
The question of a supplying strategy also arises, i.e. whether the military took part in tax collecting (most of all in goods collected as taxes), bought directly for its needs or had contracts according to which needs were satisfied. No matter how food was obtained for each Roman soldier, it is most likely that the basic food and drinking supplies were of the same kind throughout the Empire. Data from written sources or archaeological finds from other provinces could help in making the picture of food supplying in the Upper Moesia complete. Egyptian papyroi from $6^{\text {th }}$ century give data about daily needs of an average Roman soldier from about $360^{1}$ (Jones 1973: 628; Campbell 1994: 18-185). The sorts of foods and their ammounts do not differ from those from the time of the Principate ${ }^{2}$ (Davies 1989: 187, 191; Kehne 2007: 326). The authors support Roth's opinion, according to which the quantity of food stated in written sources was the one a soldier could claim, but not always the one he would receive, because it could have been substituted with something else - other goods or money. At the same time, according to the same sources, the cavalrymen, centurions and other officers were given greater ammounts of food, which could just be imaginary, since the quantity of food gained by both was most likely the same (Roth 1999: 15).

The suplying responsibility for soldiers in provincies lied in the hands of a province's governor (legatus Augusti). Province's governors were connected to military procurators (frumentarii). A frumentarius was first a soldier in charge of supplying military with grains, but later on, this function became connected to military intelligence service of Rome in provincies.

In Historia Augusta, such men often appear as spies or assassins. In time, their reputation became so bad that in 4th century, their titles were

1 Daily supplies of a soldier included: 3 libras of grain, 2 libras of meat, 2 pints of wine, $1 / 8$ pint of oil.

2 Vegetius dedicated a whole chapter of his work De re Militari to the question of supplying the Roman military, in which he named basic logistic principles. 
changed from frumentarii, (pestilens frumentariorum genus - called "filthy merchant kin" by the local populationod) to agentes in rebus (secret military intelligence) (Nelis-Clement 2000: 118).

At the territory of Viminacium, a monument was discovered with the name of a frumentarius (Mirković 1986: inscription no. 47, 84). One can still not say whether he was connected to grain supplying of the military in this area or played a role of a spy sent from Rome.

While discussing the problem of supplying and transporting goods for Roman troops, D. Breeze tried to give an answer by stating a hypothesis about four ways of food supplying (Breeze 2000: 59-64). ${ }^{3}$

When supplying Roman fortresses along the Limes in the Upper Moesia, about which there is the most data so far, there is an opinion among authors who dealt with this problem that such a supplying was pretty much organized from other towns in the hinterland of the province (Петровић 1981: 53-62; Петровић 1983: 285-291).

Horreum Margi ${ }^{4}$ could have represented such an important point for gathering and distributing food, most of all grain, owing to its position on the main crossroad, which made access to important centres within the province easy, but also to the fortresses along the Limes. Therefore it is not strange to think that Horreum Margi was in charge of supplying troops along the Iron Gates Limes. On the other hand, it is certain that withing military camps or in their vicinity there were storage buildings, mostly grainaries, but also for other supplies intended for nourishmen of the soldiers.

The quantity of food to be stored and kept depended mostly on size and number of soldiers

3 About the municipium or a colony collecting and transporting supplies with their own means or engaging transporters for military purposes and about military which collects and transports supplies on its own or engages private transporters, although the author himself admits that there are no reliable evidence whatsoever, especially for the last way of supplying.

4 The site Horreum Margi will be spoken of further on in the paper. stationed within a camp, but also on structure and durability of the food stored. According to P. Petrović, the number of soldiers stationed along the Iron Gates Limes between Golubac (Cuppae) and Karataš (Diana / Caput Bovis) was 2000-3000 men (Map 2.) (Петровић 1981: 54). Still, even thorugh the number of soldiers stationed in the camps, the quantity of food which was kept was much greater than the needs of each and every soldier and it was therefore necessary to build bigger storage buildings on different locations. Granaries must have existed in all legionary camps that supported smaller forts along the Limes. Such legionary camps were in Singidunum (IV Flavia) and Viminacium (VII Claudia). The question of river ports on these location arises as well.

The fortified port of Singidunum was not excavated because in 1875, the Serbian Royal Army filled in the complete Belgrade Danubian port basin. This was mentioned by Kanitz who saw these works during his travels across Serbia (Kanitz 1892: 5). This port was most likely fortified at the same time with the camp, thus making it a single fortified complex. M. Popović stated a hypothesis about certain parts of the Danubian fleet stationed in Singidunum, although there is no mention of these in written sources (Поповић 2006: 39). According to Popović, the position of fortification walls reaching downhills towards the river bank is similar to defensive systems applied on some of the fortresses of the Iron Gates Limes (Diana, Egeta).

Geophysical surveys of Viminacium offered plenty of data about the position of principi$u m$, buildings and barracks inside legionary camp, but without excavations, neighter of these at the momment cannot be designated as granary.

Presence of fleet is confirmed at Viminacium in Notitia Dignitatum - Prefectus Classis Histricae, and several inscriptions. River port at Viminacium is logical and necesary. It is still discussed wheather there is one or two ports whose locations are suggested after remote sensing and 
field surveys. Unfortunatelly only future excavations on these points can reveal exact situation.

Buildings discovered at the mouth of the Porečka river offer some more data about the problem of supplying along the Upper Moesia Limes (Петровић 1981: 53-62; Петровић 1983: 285-291). The site is situated on a very convenient position, in the vicinity of one of the biggest camps of the Danubian Limes - Taliata (Veliki Gradac), which had soldiers stationed permanently throughout the Roman and Early Byzantine periods (Поповић 1984: 265-282). At the same time, Porečka reka represented an important crossroad on this Limes part. There was a road which lead towards the east, over Miroč and a station called Gerulata (in the Tabula Peutingeriana), to Egeta and after that connected to the Lower Danube valley, going around the cataracts of the Iron Gates (Tabula Peutingeriana segm. $V I$ ). The road towards the south lead to the Timok valley. It is most likely that there lied the border of the two Late Antique provinces: Moesia Prima and Dacia Ripensis (Острогорски 1959: 54-56; Мирковић 1994: 93).

The mouth of the Porečka river was closed with a stone wall, while on the right river bank, there were two rectangular towers (Fig. 1.). The most interesting features are two broad buildings of approximately the same size. Building A was made of bricks and stones, with no inner walls, with a broad entrance facing the south, while the building B was made of stone, with two pillars in its interior (Fig. 2). The building was filled with huge ammounts of debris, with bricks on which fire traces were visible. Shards of larger pottery vessels were also found, used for transporting and storing food: pithoi and amphorae. Metal objects were also numerous: three bronze bells, a sickle, an ax, a bigger iron spoon and other tools.

Inside of this complex, a quadriburgium was errected close to the wall which closes the river valley (Петровић 1981: 57-61, сл. 4, 5). On the south side there was a broad main entrance, while there was a narrower one in the north, towards Danube. No objects or other archaeological finds were discovered within the fortress, except for the larger ammount of roof-tiles next to the eastern wall, which could indicate existance of an object close to this side. Sporadical amphorae fragemnts are the only archaeological material discovered inside the forts walls. ${ }^{5}$

Regarding hisotrical context and changes which took place during the Late Antiquity, it is possible to determine the function and chronological frame of the objects described above.

The objects A and B can be dated into the first half of $4^{\text {th }}$ century, which is supported with coins of Constantine, Constantius, Valens and Valentinianus (Петровић 1981: 57). Such a conclusion is also supported with the fact that there are no older building phases of these objects, nor later reconstructions of the same. The fortress was most probably built earlier, during Diocletian's great building activity and his attempts to consolidate the Limes throughout the Empire (Alföldi 2001: 154-167). ${ }^{6}$ Still, archaeological research conducted at this site ${ }^{7}$ showed that during the second half of 4th century, the fortress lied in debris, since in its southeaster part, thermae were build upon the tower (Петровић 1983: сл. 6). Although the building period of the thermae is not certain, it is possible to determine its period of collapsing, since a smaller hoard was discovered in a sooth layer upon the thermae. The youngest one among the coins were those from 378. This date can be considered as terminus ante quem for its dating.

5 Since the western wall could not be detected and since there was no archaeological material or cultural layers, it was presumed that the river destroyed the most part of the fort.

6 One should also mention Diocletianus' ravels along the Iron Gates in 294, from Singidunum to Ratiaria and further on down the Danube. The building activity was confirmed on numerous inscriptions discovered in forts along the lower Danube valley, errected most likely in the period from 298 to 299.

7 Field survey of the site began already in 1962 and the systematic excavation took place between 1967 and1970. The excavation was conducted by D. Vučković-Todorović. 


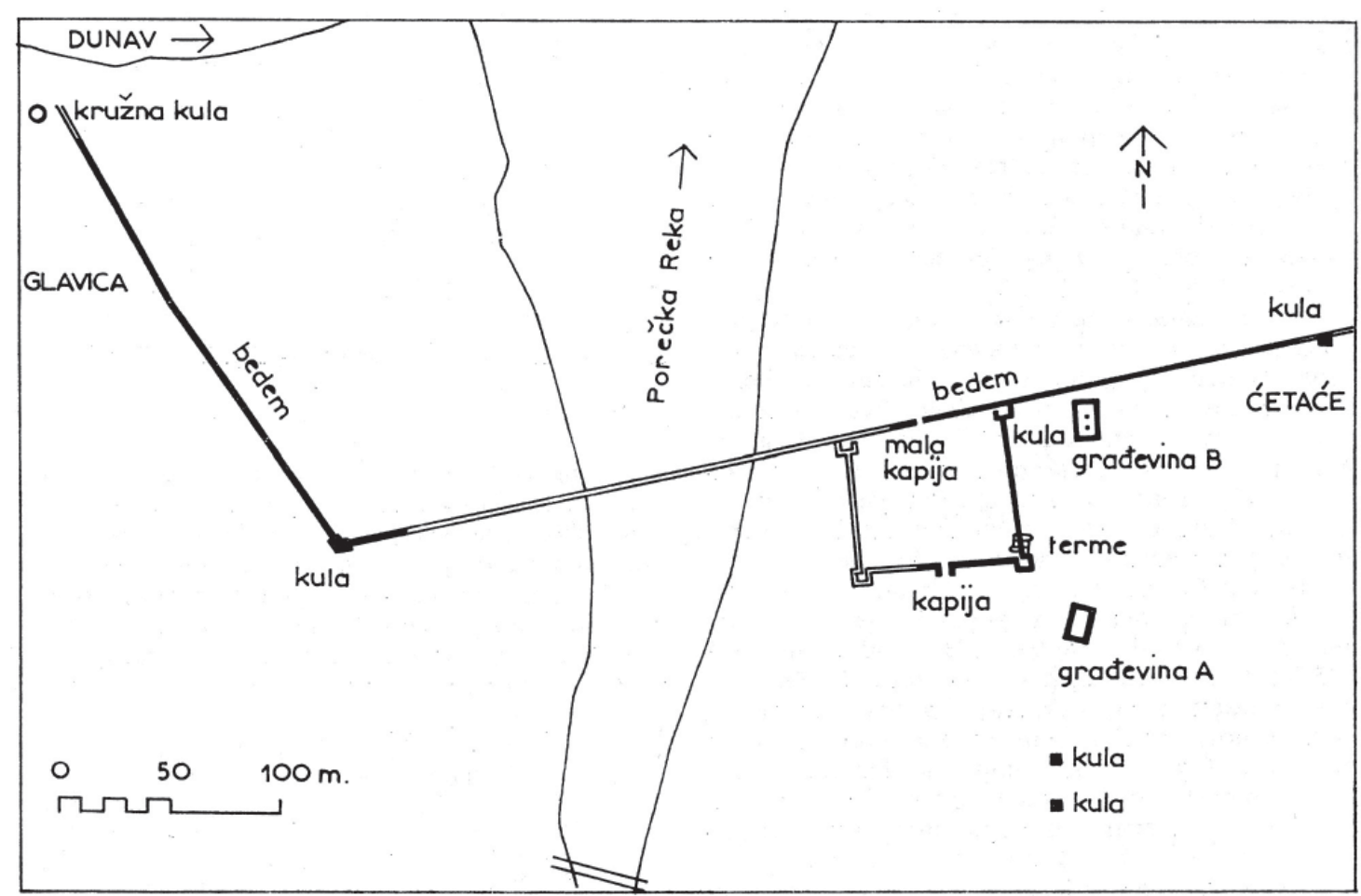

Fig. 1. Porečka reka fortification complex (П. Петровић 1981, fig. 3)

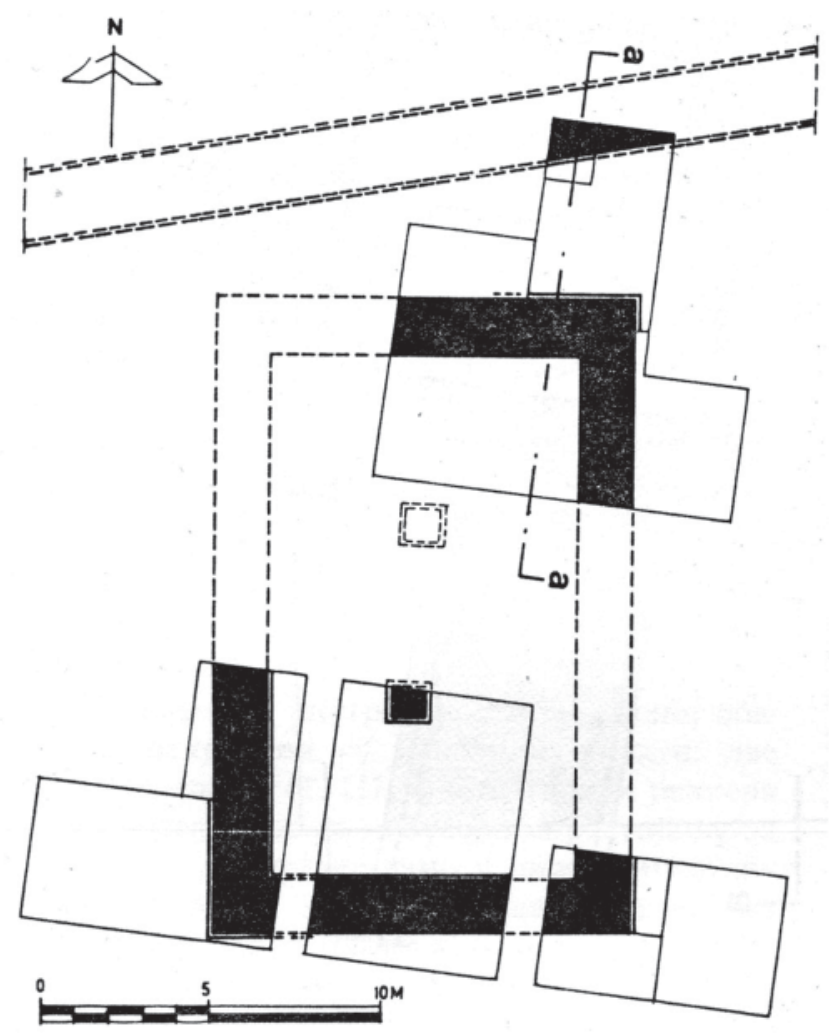

Fig. 2. Building B in fortification complex Porečka reka (П. Петровић 1984, fig. 7) 
Reforms of Diocletianus also regarded the question of military supplying. Construction of a building related to supplying happened simultaneously with introducing military taxes (annona militaris). In imperial edicts which regard these questions, preserved within the Codex Theodosianus, supplying and distributing food was organized by the officers (primipilares) (Jones 1973: 626 with named sources). They were in charge of the horrea outside the military camps, which represented supply centers from which food was distributed. Some of these granaries were located in the neighbouring towns, on greater or smaller distances from the border. There were also other buildings for supplying (loca) mentioned by Amianus Marcellinus (XIV 2, 13), representing isolated fortified centers on the border itself. It was most likely that the mouth of the Porečka river represented such a supply center from which further distribution was done. This conclusion is supported with the position of the fortification close to important military camps along the Danubian Limes. Apart from that, the buildings discovered definitely had an economic function as well. According to its plan, the building B could have been a horreum, most likely also the building A. Sporadical finds of amphorae fragments in the inside of the fortress, with no dwelling traces, indicate food storage. In the Roman Empire, examples are known of storage buildings surrounded with walls (Rickman 1971: 266-267, fig. 66).

Two other sites are considered to have been logistic centres at the Danubian Limes in the Upper Moesia: Kurvingrad and Konopište near Kostol (Pontes) (Popović 1996: 101-103).

There are very few archaeological data for both sites. At the site Konopište, $3 \mathrm{~km}$ upstreams from Trajan's brigde and the fort Pontes, foundations of irregular rectangular buildings were discovered (Popović 1996, fig. 1). In the eastern part of the excavated area, a smaller building was discovered. Another one was explored to the west that was divided into five rooms. These buildings were made of stone and mortar. A small number of archaeological finds, mostly amphorae shards from $1^{\text {st }}$ and $2^{\text {nd }}$ century, were found within these buildings, as well as a good preserved sestertius of Nerva from $97 \mathrm{AD}$ that give data about chronology (Popović 1996: 102-103).

The site Kurvingrad, today under water, was located one kilometer downstream from Konopište. At the excavated area, buildings used for storing and keeping grain and other goods were discovered. Dimensions of the horreum could not be determined because of erosion. Few finds included amphorae shards, also from the end of $1^{\text {st }}$ and the beginning of $2^{\text {nd }}$ century (Popović 1996: 103).

These two buildings represented a unique complexes errected by the Romans upon the Danubian terrace in the area from Konopište to Kurvingrad.

The remains of these buildings indicate that there was a horreum in this area and other buildings used for storing food, as well as barracks for the soldiers (Fig. 3.).

Amphora shards, as well as coins, indicate dating from the end of $1^{\text {st }}$ to the beginning of $2^{\text {nd }}$ century, actually a time when Trajan's bridge was built and when accomodation and food supplies were needed for its builders. Since most of them were brought from different parts of the Empire and were stationed here only temporarily, the buildings in which they dwelt were not of permanent character and built of short-lasting material, mostly wood, so their remains were not preserved. It is possible that convoys with food supplies were sent along with military units and builders.

Horreum Margi is mentioned as an important supply and distribution center of food (Petrović 1979: 57-61; Vasić 1990). Its municipal status indicates its basic function in a way (CIL III 7591. CIL VI 2388, no. 8). ${ }^{8}$ It was built in the Morava valley, situated at the mouth of the river

8 An inscription from 224 indicates that the town was a municipium already. 


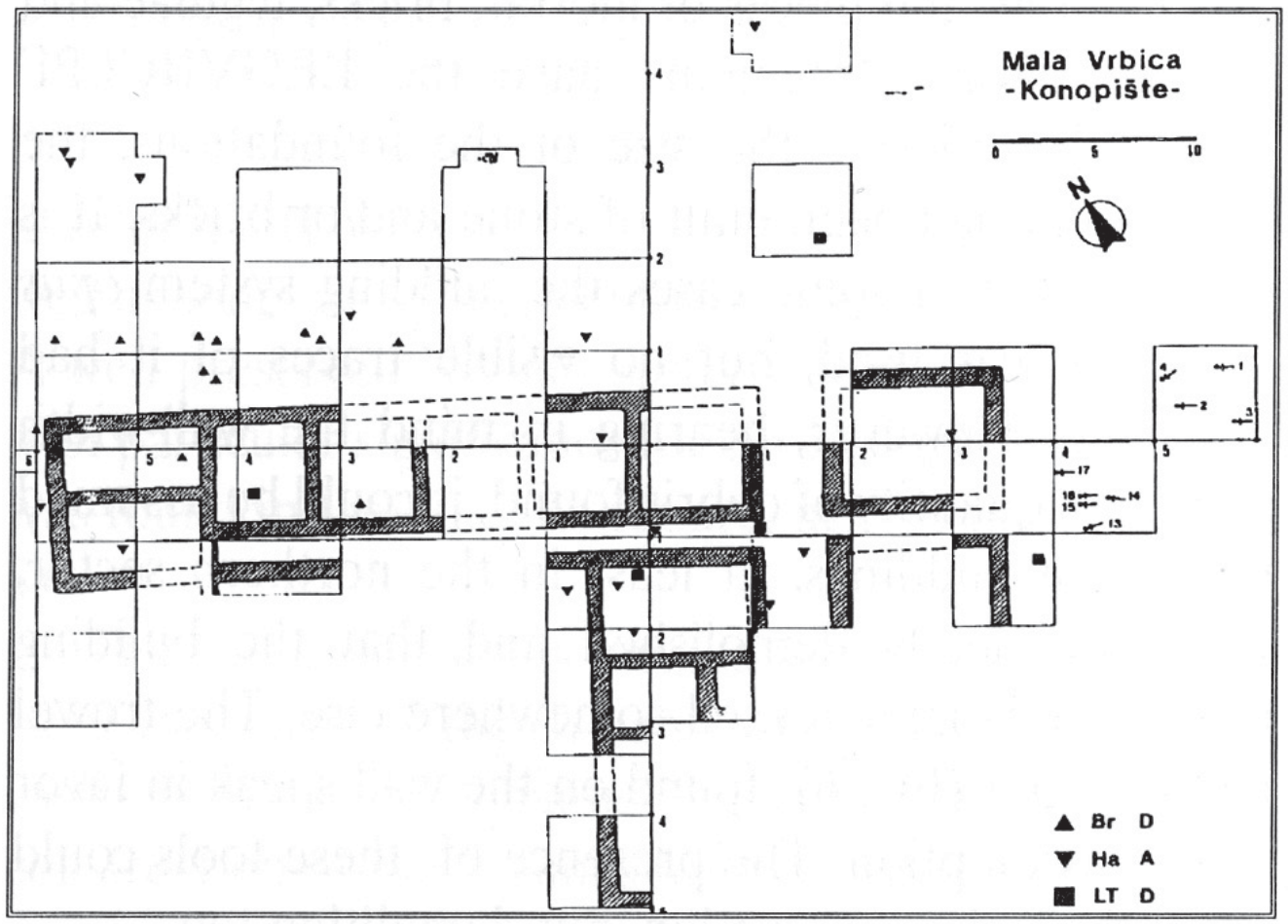

Fig 3. Plan of complex in Konopište (Popović 1996, fig. 1)

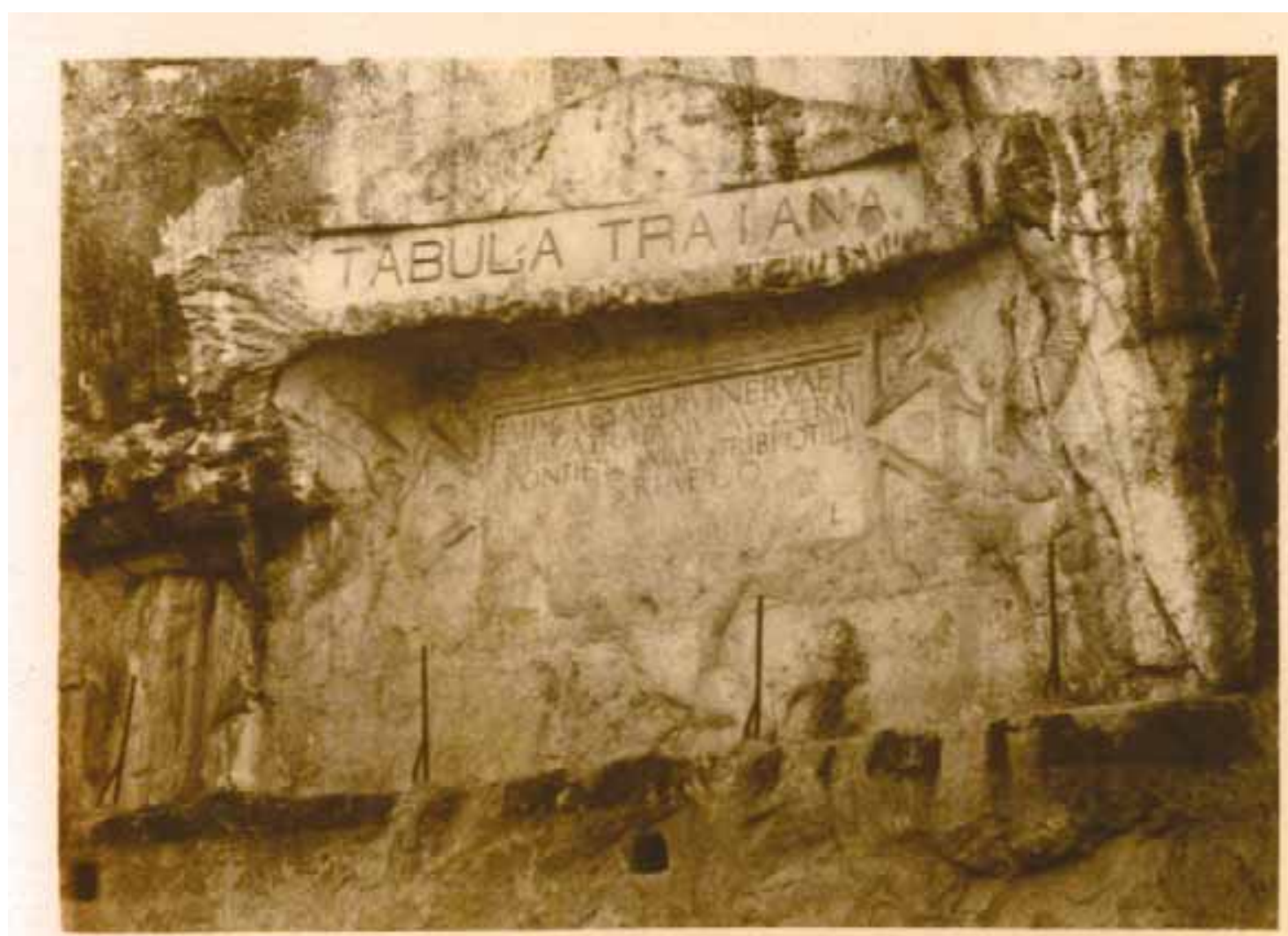

Fig. 4. Tabula Traiana, image taken on original location 
Ravanica into Morava. It was well known from earlier itineraries and from Notitia Dignitatum. ${ }^{9}$ It was positioned at the main road from Singidunum towards Naissus, one of the main centres for the whole Balcan region and next to Velika Morava, flowing towards the north i.e the Danube, close to Viminacium, the capital of the province (Korać, Golubović and Mrđić 2009). Because of this, already in $1^{\text {st }}$ century, the settlement grew very quickly from a small town into an ideal place for a supplying centre for military campaigns. Later on, it became the main base for grain distribution which was sent to smaller logistic centres along the Danubian Limes (Rickman 1971: 318). It kept its basic function as a supply center for military garrisons in the later period, even though the town grew bigger and became a municipium. In the Notitia Dignitatum, Scutaria Horreomargensis is mentioned as one of the important centres in Illyricum, under the command of Magister Officiorum (Not. Dign. Or. XI 39). Remains of a bridge over the Morava, mentioned by Kanitz (Kanitz 1892: 68-71) testify about the importance of this area for the Empire.

Apart from major supply centers, in which food was kept for further distribution, forts along the Limes had to have their own buildings intended for food storage for the soldiers stationed in them. According to Tacitus, the horreum of each camp was built and constructed in such a way to hold a one year food supplies for soldiers stationed there. Althought these data regard fortifications in Britain during the second half of $1^{\text {st }}$ century, it can easily be presumed that the same principle was valid throughout the Empire (Tacitus, Agricola - http:// www.sacred-texts.com/cla/tac/ag01020.htm).

Such measures were needed in cases of inconvenient circumstances along the Limes or bad weather conditions which could cause problems

9 Ptolemaius mentioned this place under the name of $\mathrm{Or}$ rea, among the cities in Moesia Superior (Ptolem. Geogr. III 9,4); It is also well known from the itineraries and Notitia Dignitatum: Tab. Peut. segm. VI; Itin. Ant. 134, 3; Itin. Hieros 565, 6-7; Not. Dign. Or. XI 39. in food transporting. Several horrea were discovered along the Upper Moesian Limes, within fortifications of different sizes and shapes: in Sapaja (Димитријевић 1984: 29-71), Čezava (Novae) (Васић, 1984: 91-122), Boljetin (Smorna) (Зотовић 1984: 211-225), Veliki Gradac (Taliata) (Поповић 1984: 265-282). Forts of smaller dimensions did not have enough room for such buildings.

Transportation along limes had to be combined: over land and river communications. The system of supplying over land was well-developed, with a wide network of roads. Problems regarded small weights carried by animals and charts. On the other side, dangers along land-roads could have been caused by robbers (latrones) or barbarian intruders in wartimes. Therefore each valuable transport had to be escorted. The main communication was the road along the Danube, connecting all of the Limes fortifications, and special importance was given to the road through the Iron Gates (Fig. 6), made in extreme conditions and praised on several imperial tablets. These tablets (Fig. 4) celebrate the legions involved in cutting the road through the Iron Gates and later also in its improvement and repairing (Петровић 2004: 71-95; Šašel 1961: 156-164). The importance of tranport and supply is indicated with extreme attempts to enable passage on and along the Danube. Building of the Sip canal near Diana (Statio Cataractarum Dianae) under the reign of Trajan was praised as an incredible effort, since only with this canal, the Danube became fully navigable, since the dangerous cataracts were avoided (Петровић 1972: 31-39).

Whenever it was possible, transport of food and other goods was performed over river. Rivers were used, connected with canals or pulling service for upstream navigation. It is regarded that provincial fleets also transported supply for the ground troops (Breeze 2000: 59; Kehne 2007: 328-329). Supplying was done along all of the major rivers within the Empire: the Rhine, the Danube, the 
Ilić et all, Supplying and Transport along Danube...(61-76) Archaeology and Science 6 (2010)

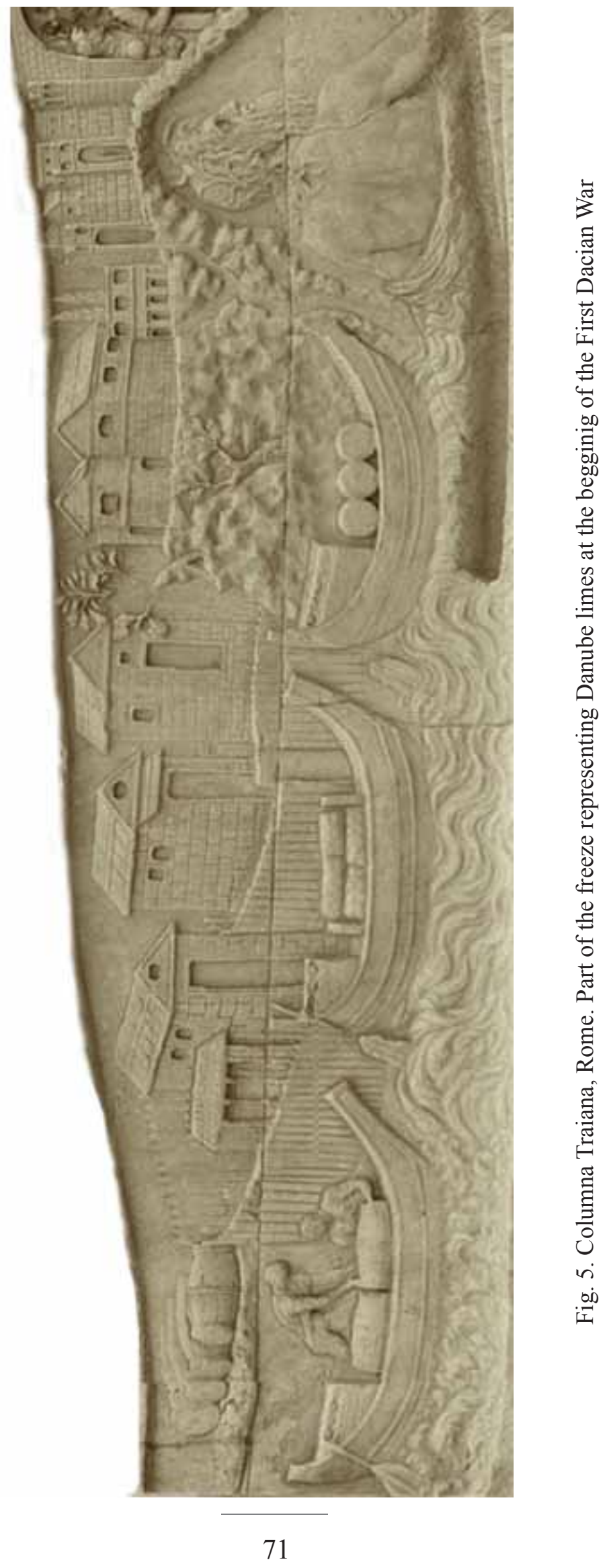


Nile, the Euphrates etc. Transport along the Danube can also be seen on Trajan's column (Fig. 5). We can also presume that to the already mentioned great storage building in Porečka river and other Danubian forts, supplies were brought from other parts of the Empire, as well as from the hinterland of the province, mostly along rivers. Actually, the main feature of all of the fortifications along the Danube was river transport. In accordance to this, all of the fortifications had to have a port or any kind of dock, out of which only a few were investigated during the great protective excavations of the Iron Gates (Петровић 1990: 207-216).

A certain Ulpius Antonius Quintus is known as aedilis and questor of the municipium in Drobeta, who decorated the port (portus) in Tekija (Transdierna) with Iuno's sculpture (Петровић 1990: 208 with earlier literature).

As ports of the Upper Moesia, Margum (Classis Stradensis et Germensis), Viminacium (Prefectus Classis Histricae), Egeta (Classis Aegetensium Sive Secunda Pannonica) and Ratiaria (Classis Ratiarenses) are mentioned in Notitia Dignitatum. The fleet was confirmed only in 92 (CIL XVI 37), although it most likey existed in the previous decades as well (Петровић 1991: 207-208). The existence of Neptune's temple as a feature directly related to the river and river transport was confirmed on several monuments discovered in Viminacium (Mirković, 1986: 75).

The most important ports were those next to the legionary camps in Singidunum and Viminacium, about which there is very few information. Smaller ports were located in Tekija (Transdier$n a$ ), Čezava (Novae), Hajdučka vodenica, Karataš (Statio Cataractarum Dianae), Brza Palanka (Egeta) and Kusjak near Prahovo (Aquae). Viminacium, Aquae and Novae had ports separated from the main fortification, while on the other sites ports were situated next to the fortifications and were protected with perimetral walls relying on the main defensive wall of each of the fortifications. Such a positioning of ports is known from
Singidunum, Hajdučka vodenica, Diana, Egeta. In German literature, such fortified ports are described as Landeburg and they are often encountered along the Rhine, although less along the middle and the lower Danube valley (Петровић 1991: 207-216).

The complex system of supplying and distributing of goods at the territory of the province of Upper Moesia, later First Moesia, was conducted along land - and river communications throughout the Roman period. Unfortunatley, possible river ports and stations are archaeologically very poor documented.

Apart from greater supply centers, in which food supplies were stored and kept for further distribution (Porečka reka, Horreum Margi), according to the archaeological data preserved, forts along the Limes also had their own buildings intended for keeping and storing food for the soldiers stationed within them for a certain period of time. The supply system used by the Roman army and the way of collecting supplies within greater supply centers indicate that the quantity of grain produced in the province of the Upper Moesia was not sufficient for all of the inhabitants and soldiers stationed at its territory. This lack was covered with the import from the neighbouring provincies, from the areas around the Black Sea and Dacia, but also from distant parts of the Empire. 


\section{BIBLIOGRAPHY}

Alföldi, M. R. 2001

PROVIDENTIA AUGUSTI. To the question of Limes fortifications in the 4th century, in Gloria Romanorum: Schriften zur Spatäntike, Stuttgart: Franz Steiner Verlag: 154-167.

\section{Bjelajac, Lj. 1996}

Amfore gornjomezijskog Podunavlja, Beograd: Arheološki institut.

Bohec, Y. 2000

The Imperial Roman Army, London: Routledge.

\section{Breeze, D. 2000}

Supplying the Army, in: Kaiser, Heer und Gesellschaft in der Römischen Kaiserzert: Gedenkschrift für Eric Birley, G. Alföldy, B. Dobson, W. Eck (Hgs.), Stuttgart: Steiner, 59-64.

\section{Campbell, B. 1994}

The Roman Army 31 BC-337 AD, London, New York: Routledge.

\section{Davies, R. W. 1989}

Service in the Roman Army, Edinburgh.

\section{Димитријевић, Д. 1984}

Сапаја, римско и средњевековно уврђење на острву код Старе Паланке, Старинар XXXIIIXXXIV: 29-71.

\section{Herz, P. 2007}

Finances and Cost of the Roman Army, in: $A$ Companion to the Roman Army, P. Erdkamp (ed.), Malden-Oxford-Carlton: Blackwell Publishing, 306-322.

Rickman, G. 1971

Roman Granaries and Store Buildings, Cambridge: University Press.

\section{Jones, A.H.M. 1973}

The Later Roman Empire II, Oxford: Basil Blackwell.

\section{Kanitz, F. 1892}

Römische Studien in Serbien. Der Donau-Grenzwall, das Strassennetz, die Städte, Castelle, Denkmale, Thermen und Bergwerke zur Römerzeit im Königreiche Serben: Wien: Tempsky. (Denkschriften der Kaiserlichen Akademie der Wissenschaften, Philosophisch-Historische Classe, 41,2. Wien, 1893).

\section{Kehne, P. 2007}

War- and Peacetime Logistics: Supplying Imperial Armies in East and West, in: A Companion to the Roman Army, (ed.) P. Erdkamp, MaldenOxford-Carlton: Blackwell Publishing: 323-338

Korać, M., Golubović S. and Mrđić N. 2009 Itinerarivm Romanvm Serbiae, Belgrade: Center for New Technologies.

\section{Mason, D. J. 1988}

Prata Legionis in Britain, Britannia 19: 163-189.

\section{Мирковић, М. 1981}

Историја Српског народа I, Београд: Спска књижевна задруга: 89-104.

\section{Mirković, M. 1986}

Inscriptions de la Mésie Supérieure, vol. II (Viminacium et Margum), Beograd: Centar za antičku epigrafiku i numizmatiku.

\section{Mocsy, A. 1967}

Zu den Prata legionis, Studien zu den Militärgrenzen Roms 6, Internationale Limes kongress 1964, Köln Graz: Böhlau Verlag, 211-214.

\section{Mocsy, A. 1972}

Das Problem der militärischen Territorien in Donauraum, Acta antiqua Acad. scient. hung. XX: 133-168 


\section{Nelis-Clement, J. 2000}

Les Beneficiarii: militarises et administrateurs au services de l'Empire (Ire s. a. C. - VIe s.p. C), Bordeaux: Ausonius.

\section{Острогорски, Г. 1959}

Историја Византије, Београд: Просвета.

\section{Петровић, П. 1972}

Нова Трајанова табла у Ђердапу. Старинар XXI: 31-39.

\section{Petrović, P. 1979}

Inscriptions de la Mésie Supérieure, vol. IV, (Naissus, Remesiana et Horreum Margi) Beograd: Centar za antičku epigrafiku i numizmatiku.

\section{Петровић, П. 1981}

О снабдевању римских трупа на ђердапском лимесу, Старинар XXXI: 53-62.

\section{Петровић, П. 1984}

Поречка река, сабрини центар за снабдевање римских трупа у Ђердапу, Старинар XXXIIIXXXIV: 285-291.

\section{Петровић, П. 1991}

Classis Flavia Moesica на Дунаву у Горњој Мезији, Старинар XL-XLI: 207-216.

\section{Петровић, В. 2004.}

Екскурси о римским старинама на подручју Ђердапа у делу Беле де Гонде. Балканика XXXIV (2003): 71-95.

\section{Поповић, М. 2006}

Београдска тврђава, Београд: Јавно предузеће „Београдска тврђава““.

\section{Popović, P. 1996}

Konopište - Roman Architecural Complex, in: Roman Limes on the Middle and Lower Danube, P. Petrović (ed.), 101-104. Belgrade: Archaeological Institute.

\section{Поповић, В. 1984}

Доњи Милановац - Велики Градац (Taliata), римско и рановизантијско утврђење, Старинар XXXIII-XXXIV:265-282.

Roth, J.P. 1999

The Logistics of The Roman Army at War (264 B.C. - A.D. 235) Leiden-Boston-Köln: Brill.

\section{Šašel, J. 1961}

Rimski natpisi u Đerdapu, Limes u Jugoslaviji I: 156-164.

\section{Tacitus}

Agricola - http://www.sacred-texts.com/cla/tac/ ag01020.htm

\section{Thomas, R., Stallibrass, S. 2008}

For starters: producing and supplying food, in: Feeding the Roman Army the Archaeology of Production and Supply in NW Europe, R. Thomas, S. Stallibrass (eds.), Oxford: Oxbow Books, 1-17.

\section{Васић, М. 1984}

Чезава-Castrum Novae, Старинар XXXIIIXXXIV: 91-122.

Vasić, M. 1990

Horreum Margi (Ćuprija), Beograd: Arheološki institut.

\section{Zaninović, M. 1985}

Prata legionis u Kosovu kraj Knina s osvrtom na teritorij Tilurija, Opuscula Archaeologica, 10: 63-79.

\section{Зотовић, Љ. 1984}

Бољетин (Smorna), римски и рановизантијски логор, Старинар XXXIII-XXXIV: 211-225. 
REZIME

SNABDEVANJE I TRANSPORT NA DUNAVSKOM LIMESU U GORNJOJ MEZIJI

Ključne reči: snabdevanje, sabirni centri, Dunavski limes, rečna pristaništa, Gornja Mezija.

Snabdevanje i distribucija namirnica tokom rimskog perioda na teritoriji provincije Gornje Mezije obavljani su i vodenim i kopnenim putevima. Kada govorimo o limesu Gornje Mezije, problem možemo analizirati sa dva aspekta:

- jedan se odnosi na geografske celine, odnosno na prostor između Singidunuma i Đerdapa, samu Đerdapsku klisuru i prostor nizvodno od Đerdapske klisure.

- drugi je snabdevanje vojske prema rangu jedinica, odnosno legija ili pomoćnih, auksilijarnih, trupa.

Sistem snabdevanja vojske hranom otvara mnoga pitanja koja se tiču pre svega načina njene nabavke iz udaljenih područja ili iz regiona, odnosno nabavka od lokalnog stanovništva.

Snabdevanje vojnih logora na gornjomezijskom limesu u znatnoj meri je organizovano iz drugih gradova u unutrašnjosti provincije. Horreum Margi je mogao biti jedna takva važna baza za prikupljanje i distribuciju prehrambenih proizvoda, pre svega žitarica, zahvaljući povoljnom položaju na glavnim komunikacionim pravcima, kako suvozemnim tako i rečnim, što je omogućavalo lak pristup važnim centrima i đerdapskim utvrđenjima. S druge strane, sasvim je izvesno da su se i u logorima ili njihovoj neposrednoj okolini nalazila skladišta, u prvom redu žita, a potom i drugih namirnica namenjenih ishrani vojnika. Za sagledavanje problema snabdevanja na gornjomezijskom limesu nešto više podataka pružaju objekti otkriveni na ušću Porečke reke. Locirana na izuzetno povoljnom geografskom položaju, u neposrednoj blizini jednog od najvećih logora na dunavskom limesu - Velikog Gradca (Taliata), Porečka reka je predstavljala i važnu raskrsnicu puteva u ovom delu Limesa. Pored ovog lokaliteta, kao mogući logistički centri na gornjomezijskom delu Dunavskog limesa pominju se i Kurvingrad i Konopište kod Kostola (Pontes). Osim velikih sabirnih centara u kojima su bile smeštane i čuvane zalihe hrane za dalju distribuciju, tvrđave na limesu su morale imati i sopstvene objekte namenjene odlaganju i čuvanju namirnica koje su mogle za izvesno vreme da zadovolje potrebe vojnih posada smeštenih u njima.

Način dopremanja namirnica morao je biti kombinovan, odnosno kopneni i rečni.

Sistem snabdevanja kopnenim komunikacijama bio je dobro razvijen, a mreža puteva razgranata. Osnovna komunikacija bio je put duž Dunava koji je povezivao fortifikacije na limesu, a poseban značaj imao je put kroz Đerdapsku klisuru prosecan u ekstremnim uslovima čiju gradnju slavi niz carskih tabli. Transport namirnica i ostalih proizvoda obavljan je vodenim putevima kad god je to bilo moguće. Rečni tokovi su bili maksimalno korišćeni, često povezani kanalima ili vučnom službom. Smatra se da su provincijske flote prevozile namirnice za rimsku vojsku. Okosnicu snabdevanja fortifikacija na Dunavu činio je rečni transport, tako da su fortifikacije morale imati neki oblik pristaništa, ali samo nekoliko je istraženo u okviru velikih zaštitnih iskopavanja Đerdapa. Kao luke na prostoru Gornje Mezije pominju se Margum, Egeta i Viminacium.

$\mathrm{Na}$ kraju možemo da zaključimo da sistem snabdevanja koji je koristila rimska vojska i način stvaranja zaliha unutar većih sabirnih centara, upućuje na to da proizvodnja pre svega žitarica, ali i drugih životnih namirnica u oblasti Gornje Mezije nije bila dovoljna za ishranu stanovništva i vojske stacionirane na njenoj teritoriji. Taj nedostatak je najverovatnije nadoknađivan uvozom iz susednih provincija, iz oblasti oko Crnog mora i Dakije, ali treba računati i na uvoz iz udaljenih oblasti Carstva. 


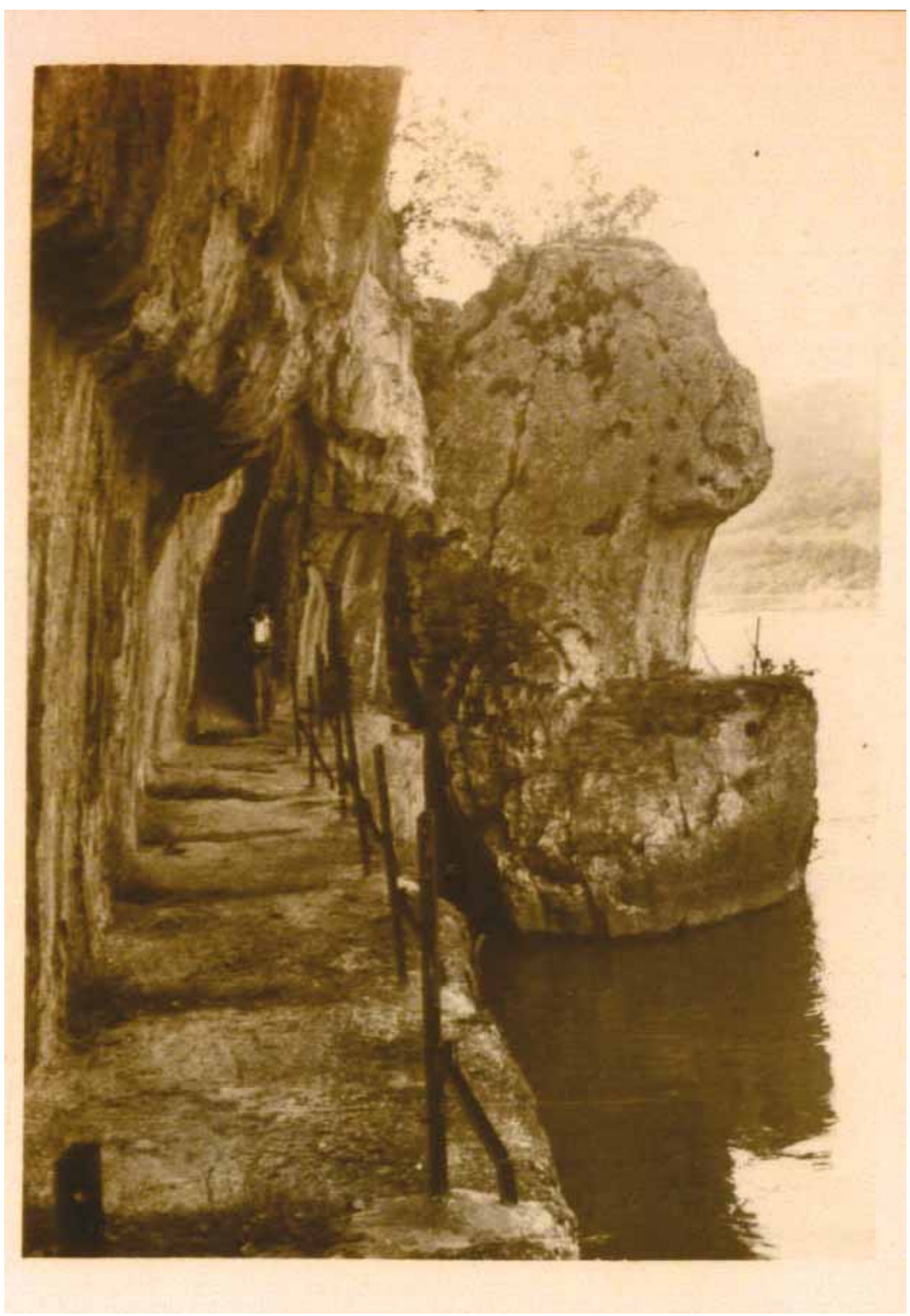

Fig. 6. Roman road cut into the rocks of the Iron Gate gorge 